Boston University School of Law Scholarly Commons at Boston University School of Law

Faculty Scholarship

$11-2013$

\title{
The New Constitution of the United States: Do We Need One and How Would We Get One?
}

Jack M. Beermann

Boston University School of Law

Follow this and additional works at: https://scholarship.law.bu.edu/faculty_scholarship

Part of the Constitutional Law Commons

\section{Recommended Citation}

Jack M. Beermann, The New Constitution of the United States: Do We Need One and How Would We Get One?, No. 14-4 Boston University School of Law, Public Law Research Paper Series (2013).

Available at: https://scholarship.law.bu.edu/faculty_scholarship/59 


\section{BU School of Law}

\section{The New Constitution of the United States: Do We Need One And How Would We Get One?}

Boston University School of Law Working Paper No. 14-4

(January 21, 2014)

Jack M. Beermann

Boston University School of Law

This paper can be downloaded without charge at:

http://www.bu.edu/law/faculty/scholarship/workingpapers/2014.html 
Beermann, The New Constitution, 11/18/2013

The New Constitution of the United States: Do We Need One and How Would We Get One?

\author{
Jack M. Beermann ${ }^{*}$
}

As the contributions to this symposium illustrate, there is great disagreement over whether the constitutional order of the United States suffers from serious dysfunction and if so whether the Constitution should be amended or replaced. One reason for the disparity of views is the lack of a unifying conception of dysfunction. In my view, the constitutional order of the United States suffers from three distinct problems, a democracy deficit, gridlock and the overproduction of bad law and policy. ${ }^{1}$ Although I recognize that there may be disagreement over whether each of these problems exists and whether, if they do, whether they are serious enough to warrant reform, I find enough problems on all three scores to warrant serious consideration of reform.

It is appropriate to view the constitutional order holistically, rather than focus on whether any particular constitutional provision needs fixing or should be scrapped. Understood this way, the Constitution of the United States includes the text of the document adopted in 1789, the amendments adopted under the Constitution's Article V process and all of the features of federal and state government produced under the order created, facilitated and allowed under the written Constitution. The best way to think of this is to adopt the position of an outsider - a person from

\footnotetext{
* Professor of Law and Harry Elwood Warren Scholar, Boston University School of Law. This article was prepared for the conference America's Political Dysfunction: Constitutional Connections, Causes, and Cures, held at Boston University School of Law on November 5-6, 2013.

${ }^{1}$ I will not take the time to provide numerous examples of bad law, but consider, as an example, why the Food and Drug Administration cannot tell us that some forms of Vitamin E, taken in high doses, cause prostate cancer. See Food, Drug and Cosmetic Act $\S 411,21$ U.S.C. $§ ~ 350$, added in 1976 by Pub. L. 94-278, title V, §501(a), Apr. 22, 1976, 90 Stat. 410. This provision, known as the Proxmire Amendment after its champion Senator William Proxmire, restricts the FDA's authority to regulate vitamins and supplements. See National Nutritional Foods Association v. Kennedy, 572 F.2d 377, 382 (2d Cir 1978) (describing effects of 1976 legislation). This legislation was enacted in response to intense lobbying by the vitamin and supplement industry after the FDA began to take action against unsafe and ineffective vitamins and supplements.
} 
Beermann, The New Constitution, 11/18/2013

a different society is likely to evaluate the success of the constitutional order without fixating on particular words or phrases in any one document or set of documents. The proper focus is on the entire governmental system in the United States. That is what composes the constitutional order.

Government in the United States has some serious problems. Some of the problems are financial: Many State and local governments are suffering from severe financial stress, in part because they have not set aside the funds to pay for pension and health care benefits for their retirees. The federal government has brought deficit spending to a high art, with the national debt at more than $\$ 16$ trillion and growing.

Then, at the federal level, is the problem of gridlock. The United States Congress sometimes seems unable or unwilling to do anything about any serious problem (although it must have done something to run up more than $\$ 16$ trillion in debts). The Republican Speaker of the House of Representatives has decided not to bring any legislation to the floor without the support of a majority of Republican representatives, even if the legislation is favored by a majority of the American people and Members of the House of both parties combined. In the Senate, with its grossly undemocratic composition, majority rule has been supplanted by a practice of requiring 60 votes for virtually all important actions. Rather than agree on a rational set of budget cuts and tax increases to deal with the deficit, Congress and the President brought us a series of acrossthe-board cuts known as "sequestration" which operate without any sensible prioritization. As I write, we have just concluded a partial government shutdown over House Republicans' insistence that any Continuing Resolution either defund or delay the implementation of the Affordable Health Care Act and we came to the precipice of a default on obligations due to Congress's refusal to increase the limit on national debt. Forget about addressing problems such as global warming, income inequality, failing schools, economic stimulus or you name it. 
Beermann, The New Constitution, 11/18/2013

The federal courts may be the most respected branch of the federal government, but I don't understand why. Especially at the Supreme Court, for better or for worse, it has become increasingly clear that in many cases, it's politics all the way down. Are the people of the United States really comfortable with entrusting many of society's most important decisions to a group of nine unaccountable officials whose selection depends to a great extent on happenstance concerning when vacancies occur, or even worse, based on timed retirements to ensure that the retiree's political party gets to choose the successor? Supreme Court Justices have taken over important areas of campaign finance regulation, gun control, abortion law and tort policy, to name a few, and Circuit Judges, especially in the D.C. Circuit, have become super-managers of the administrative state, shaping regulatory policy through the power of judicial review under the Administrative Procedure Act.

And what has happened to the presidency? To some, the President has become much too strong and much too central, presenting the danger of unchecked adventurism in military matters, foreign affairs and domestic policy. To others, the presidency has been weakened by excessive meddling by Congress into the execution of the law. While it is tempting to say that criticism from both sides indicates that we are at a happy medium, the truth may be more complicated. The President may have been weakened in some matters while possessing excessive unchecked power in others. As Bruce Ackerman has argued, in military and foreign affairs matters, the presidency may have been transformed into an institution with more power than the Framers envisioned and the American people want. ${ }^{2}$ Is there anything to Ackerman's alarm, or is he overreacting to the excesses of the war on terror? Although Ackerman is worried about lawless presidential conduct generally, in domestic affairs, the fragmentation of the Executive Branch

\footnotetext{
${ }^{2}$ See Bruce Ackerman, The Decline and Fall of the American Republic (2010).
} 
Beermann, The New Constitution, 11/18/2013

and congressional gridlock may have disabled the President from leading the country out of its difficulties.

As Sanford Levinson has pointed out, the Constitution of the United States contains several strikingly undemocratic features. ${ }^{3}$ In my view, the two most prominent of these are the method of presidential selection and equal representation of States in the Senate. Coming in a close third is partisan manipulation of congressional districting by State legislatures. On presidential selection, tallying the vote State by State rather than through the popular vote as a whole makes little sense, and granting each State two extra votes just by virtue of their status as States makes no sense. Equal representation of the fifty States in the Senate when the Senate's legislative power is equal to that of the House of Representatives is blatantly anti-democratic. Add the Senate's constitutional power to make its own rules, which validates the filibuster, and Senators representing a small minority of the American people have power to block important initiatives. This is an ingredient of a great recipe for gridlock. Partisan districting reorients the House of Representatives from being representatives of the people to representing the State's majority party, which explains how the House remained in Republican hands despite Democratic candidates receiving about a million more votes than Republicans in the 2012 election.

So how bad is it, really? Has the United States become ungovernable, and is the Constitution to blame? In my view, it's a mixed bag. Some aspects of the United States government work very well, others are disastrous and still others muddle along, could be better but function just fine. Further, it is difficult to pin some of government's difficulties on any particular constitutional provision when the alternatives might be just as problematic. In this essay, I highlight examples in each of these categories and look at factors that might help us

\footnotetext{
${ }^{3}$ See Sanford Levinson, Our Undemocratic Constitution: Where the Constitution Goes Wrong (And How We the People Can Correct It) (2006).
} 
Beermann, The New Constitution, 11/18/2013

understand why things work as they do. Suggestions for change will be offered, often without considering political feasibility.

\section{Features That Seem to Work}

There are some aspects of the Constitution of the United States that work very well. The Postal Clause, under which the federal government established the United States Postal Service and laid out post roads, is one of my favorite parts of the Constitution. It's true that the Postal Service has fallen on hard times of late as internet-based technology has supplanted what is now referred to as "snail mail," and it may not be long for this world, but it served an incredibly important purpose when it was established. The nationwide post office ensured a cheap and simple method of communication across a vast nation, and was vital to the creation and maintenance of a national identity. Post roads were an important element of the success of the post office, and to this day they remain important if only as links to our past. Parts of the Boston Post Road, in the suburbs around Boston, originated as pathways laid out by Native Americans and link us to the network of population centers in pre-colonial and colonial times.

More seriously, the federalist structure of the government of the United States, is, in my view, generally a positive feature. In a country with as many people and as much territory as the United States, a strong form of federalism is preferable to a monolithic central government. The Framers' had a strong, and in my view justifiable, fear of a strong central government. Dividing government into multiple levels reduces the potential for tyranny. If State and local governments retain significant governmental power, the tyrant would need to capture numerous governmental units to destroy self-determination. State and local autonomy also facilitate diversity and experimentation. Diversity of government policy and programs facilitates greater selfdevelopment of people and communities while experimentation allows for smaller scale trials of 
Beermann, The New Constitution, 11/18/2013

policies and programs that, if they work, may be adopted by other States and by the central government. Many of the Constitution's structural provisions depend on the existence of viable, separate States and facilitate the positive aspects of the federalist structure. ${ }^{4}$

Although the current dysfunction in Washington may be due at least in part to gerrymandered congressional districts, allocating the redistricting function to the States minimizes the risk of nationwide gerrymandering that might lock in a minority government even more securely than in the current situation. It's a simple matter of diversification of risk. A few gerrymandered States is nowhere near as damaging as a gerrymandered nation. Of course, it would be preferable to remove politics from the redistricting process, but that's easier said than done. The same can be said about leaving the tallying of votes for President to the States. While it might be easier to steal the vote in a State than in a single federally-administered election process, the necessity of vote fraud in multiple States to win a presidential election provides some insulation against a stolen presidential election.

Federalism also has its costs. First is the raw cost of duplicative government structures. For example, it may be more expensive to run fifty-two separate judicial systems (50 States, District of Columbia and federal) than to run a single system. Second is the cost of resolving conflicts over the distribution of governmental authority. The lines between federal and State authority, and between State and local authority are often unclear. This lack of clarity may be a virtue in some circumstances - it creates struggle among political officials that forces compromise_-but in many cases it causes hesitancy and costly dispute resolution. But overall, federalism with strong local governmental units is a positive element of the American system of government.

\footnotetext{
${ }^{4}$ For an early discussion of the role of the states in the constitutional structure, see Texas v. White, 74 U.S. 700,725 (1869) ("the preservation of the States, and the maintenance of their governments, are as much within the design and care of the Constitution as the preservation of the Union and the maintenance of the National government").
} 
Beermann, The New Constitution, 11/18/2013

There is an interesting aspect in the development of American federalism that merits separate attention. Political and social morality develops differently in some parts of the country than in others. Sometimes it's a matter of the pace of change while in other situations cultural differences may be more durable. This can lead to friction when States differ substantially on hot button issues such as abortion, immigration, same sex marriage, etc. In 1973, for example, some States had very liberal abortion laws while others were quite restrictive, basically criminalizing all or virtually all abortions. The Supreme Court's ruling recognizing a substantive due process right to abortion ${ }^{5}$ had the potential to eliminate diversity among the States on abortion. However, the anti-abortion feelings in many States have remained strong, outlasting segregationist views that persisted in the aftermath of Brown v. Board of Education. ${ }^{6}$ In antiabortion States, the legislatures continue to enact restrictive abortion laws, placing the matter repeatedly before the federal courts and the Supreme Court, and the Court has retreated from the absolutist holding of Roe v. Wade and today allows substantial regulation of abortion under the undue burden standard. ${ }^{7}$

\section{Dysfunction and the Supreme Court}

I want to consider abortion jurisprudence in relation to dysfunction and then expand the discussion to the Supreme Court generally. One of the arguments made against decisions like Roe v. Wade is that they short circuit the political process. When a fundamental constitutional right is at stake, that is how it should be. As a practical matter, however, a Supreme Court decision can have unforeseen consequences that can reverberate for decades. Although this may seem like a fantastic tale, in my view, current political divisions are at least somewhat traceable to abortion law. It goes like this. Had the Supreme Court steered clear of the abortion question,

\footnotetext{
${ }^{5}$ Roe v. Wade, 410 U.S. 113 (1973).

6347 U.S. 483 (1954).

${ }^{7}$ Planned Parenthood v. Casey, 505 U.S. 833 (1992).
} 
Beermann, The New Constitution, 11/18/2013

some more States may have liberalized their abortion laws while some would have undoubtedly persisted with restrictive laws. The issue would have been politically salient, but it is unlikely that it would have become the single issue litmus test used by some voters in elections and in judicial selection in some States and by some Presidents. Because pro-choice candidates tend to be liberal on other issues, and anti-abortion candidates tend to be generally conservative, the electorate in States with anti-abortion views have tended to elect more conservative legislatures than they might have otherwise done. These conservative State legislatures have drawn congressional districts protecting conservative representatives, which has contributed to the overrepresentation of conservative ideas in the United States Congress and thus contributed to the gridlock and government shutdown of $2013 .{ }^{8}$ As was repeatedly stated during the recent government shut down and struggle over the debt ceiling, many Republican Representatives have no fear of losing a general election to a Democrat, but if they compromise with Democrats in Congress, they risk defeat in a Republican primary by a candidate attacking them from the right.

This analysis, as fanciful as it may seem to some, implicates several constitutional features as contributing to dysfunction. First and in my view foremost is the lack of guidance and restraint on the behavior of the Supreme Court. As Justice Iredell explained so long ago, "some speculative jurists have held, that a legislative act against natural justice must, in itself, be void; but I cannot think that, under such a government, any Court of Justice would possess a power to declare it so." And why, according to Justice Iredell, should courts not have the power to declare laws void for contravening principles of natural justice? "The ideas of natural justice

\footnotetext{
${ }^{8}$ Although the Supreme Court has held that allegations of partisan gerrymandering present justiciable equal protection claims, the Court has made it virtually impossible for plaintiffs to win such claims. See Davis v. Bandemer, 478 U.S. 109 (1986).

${ }^{9}$ Calder v. Bull, 3 U.S. 386, 398 (Dall.) (1798) (Iredell, J.).
} 
Beermann, The New Constitution, 11/18/2013

are regulated by no fixed standard: the ablest and the purest men have differed upon the subject; and all that the Court could properly say, in such an event, would be, that the Legislature (possessed of an equal right of opinion) had passed an act which, in the opinion of the judges, was inconsistent with the abstract principles of natural justice." ${ }^{10}$ Our constitution allows five unaccountable people to impose their views on the nation, with no realistic possibility of constitutional amendment to overrule misguided or unpopular decisions and with no responsibility for correcting the consequences of their actions.

There are areas of recent Supreme Court jurisprudence in which the conservative majority of the Court has acted without apparent regard for the consequences of the Court's decisions, namely campaign finance and gun control. While neither of these areas are governed by substantive due process, the Court's decisions rest upon debatable applications of provisions of the Bill of Rights and rest in substantial part on the Justices' views on how the Constitution should be read rather than on the meaning of the words or the intent of the Framers. In the area of campaign finance, the Court's Citizens United ${ }^{11}$ decision has unleashed a flood of corporate money into partisan politics. In a press conference on Tuesday October 8, 2013, President Obama explicitly blamed Citizens United, in conjunction with gerrymandered congressional districts, for the government shutdown. He said that many Republicans in gerrymandered Republican districts who might otherwise vote to keep the government open and raise the debt limit are afraid that if they vote to end the shutdown or raise the debt limit they will be challenged in a primary by a well-financed challenger from the right. The President said that corporate money would be financing these challengers and that Republicans are afraid to provoke them. While it is impossible to know whether President Obama is correct about the

\footnotetext{
${ }^{10}$ Id. at 399.

${ }^{11}$ Citizens United v. Federal Election Commission, 558 U.S. 310 (2010).
} 
Beermann, The New Constitution, 11/18/2013

effects of corporate money in politics, it is certain that the Justices of the Supreme Court will not suffer any untoward consequences regardless of the damage they do to American democracy.

Another extremely unfortunate feature of the political system of the United States is the never-ending campaign for Congress. The Supreme Court is largely responsible for this, because the Court would not tolerate reasonable limits on the timing and extent of political activity. Many democratic countries have limits on campaigning so that government can function normally when there is no election directly on the horizon. In the United States, the two year campaign for the House of Representatives begins the morning after the prior election, and the presidential primary season keeps starting earlier and earlier, with States racing to make their primaries early enough to matter and New Hampshire and Iowa answering by moving their primary and caucus dates up to beat the competition. Because the Supreme Court would strike down efforts to prohibit campaigning before a certain date as inconsistent with freedom of speech, all government officials are forced to behave like politicians at all times. This may seem good for democratic accountability, and it would be if not for the Supreme Court-imposed role of money, which makes politicians overly dependent on wealthy individuals and corporations for electoral support.

On gun control, the Supreme Court, ignoring decades of precedent, has recently held that there is an individual right to own handguns for self-defense ${ }^{12}$ and that the Second Amendment's rights apply against the States because they are incorporated into the Fourteenth Amendment. ${ }^{13}$ Again, these are highly debatable legal propositions and they are highly contested in the political arena. While the political process has not been completely short circuited, because State and local governments continue to test the limits of the rights recognized by the Court, the Court has

\footnotetext{
${ }^{12}$ District of Columbia v. Heller, 554 U.S. 570 (2008).

${ }^{13}$ McDonald v. Chicago, 561 U.S. 3025 (2010).
} 
Beermann, The New Constitution, 11/18/2013

severely restricted the ability of all levels of government to enact and enforce gun control measures. There is, of course, substantial debate in the United States over whether gun control reduces or increases gun crimes. This is the exact sort of debate that, in a democracy, should be resolved politically rather than legally. As it is, the Court's attitude on gun control and campaign finance evokes the image of Nero fiddling while Rome burns.

The point of bringing up the abortion, campaign finance and gun control decisions is not to express disagreement with the outcomes of the cases, but to illustrate a major defect in the Constitution of the United States, the virtually unchecked power of the Supreme Court of the United States. These three areas are but a small sample of the areas in which the Court has intervened where principles of democracy militate in favor of judicial restraint. ${ }^{14}$ The Court also engages in repeated struggles with Congress, which, for example in the civil rights area, has led Congress to repeatedly enact new statutes or amend existing ones to reverse Supreme Court decisions. ${ }^{15}$ While in some areas, the consequences do not extend beyond the social effects of the Court's preferred substantive outcome, in the campaign finance area, the Court's recent jurisprudence has the potential to undermine democracy. ${ }^{16}$ The Court is free to act without regard to the social consequences of its decisions because there is no electoral or other effective check on its behavior.

I do not want this critique to be mistaken for the familiar invocation of the "countermajoritarian difficulty" that underlies much of the discussion of judicial activism. ${ }^{17}$ Many of the governmental units whose efforts are stymied by the Supreme Court are not majoritarian.

\footnotetext{
${ }^{14}$ See generally, Jack M. Beermann, The Supreme Common Law Court of the United States, 18 B.U. Pub. Int. L.J. 119 (2008).

${ }^{15}$ See Jack M. Beermann, The Unhappy History of Civil Rights Legislation, Fifty Years Later, 34 Conn. L. Rev. 981 (2002).

${ }^{16}$ My prediction is that sometime in the not-too-distant future, the "Citizens United era" will join the Lochner era and the era of "separate but equal" in the short list of infamous periods in the Court's history.

${ }^{17}$ See generally Erwin Chemerinsky, The Price of Asking the Wrong Question: An Essay on Constitutional Scholarship and Judicial Review, 62 Texas Law Review 1207-1262 (1984).
} 
Beermann, The New Constitution, 11/18/2013

Federal statutes, for example, are shaped by the non-majoritarian Senate and the gerrymandered House of Representatives. Many State and local governments are also infected with partisan gerrymandering and the hangover of the distinctly non-majoritarian voting patterns that were produced by racially discriminatory voting laws and practices beginning in the late nineteenth century. ${ }^{18}$ Rather, my critique is based on four factors, first that the Supreme Court is less accountable and democratic than most other governmental units, second that the Court is free to act without regard to the social consequences of its actions, third that it is extremely difficult to reverse the Court's constitutional rulings due to the Constitution's very difficult amendment process and fourth that the Court contributes to the polarization of politics by cutting off healthy political debate.

It is also important to recognize that rejecting the Supreme Court's historical role in American society is not the rejection of the rule of law. The rule of law demands that government and citizens obey court decisions and work through normal political and legal channels to modify or reverse them. Most analysts who criticize the Court do not advocate disobedience, but rather reform. In a society with a well-functioning democracy that respects and protects minorities, the predominant judicial attitude should be restraint. When democracy is undermined, as it is by many of the features of the Constitution of the United States and State practices, the Courts should be vigilant and willing to correct the defects and the results of the defective processes. ${ }^{19}$ But there is no call for the general legal takeover that the Court has practiced in many periods of its history, including the current one.

So what features of the Constitution create the problem of the unaccountable Supreme Court? This is not immediately clear. Abolishing judicial review for constitutionality would

\footnotetext{
${ }^{18}$ Gabriel J. Chin \& Randy Wagner, The Tyranny of the Minority: Jim Crow and the Counter-Majoritarian Difficulty, 43 Harv. C.R.-C.L. L. Rev. 65 (2008).

${ }^{19}$ Cf. United States v. Carolene Products Co., 304 U.S. 144, 153 n.4 (1938).
} 
Beermann, The New Constitution, 11/18/2013

remove an important check on Congress and the Executive Branch. As Chief Justice Marshall explained in Marbury v. Madison, ${ }^{20}$ there is a firm basis in the Supremacy Clause and the tradition of the rule of law for judicial review of the constitutionality of statutes and other actions of Congress and the Executive Branch. Perhaps life tenure for federal judges is the culprit. Although life tenure is touted as necessary for judicial independence, a defined term with no chance of reappointment would serve the same purpose without allowing judges to perpetuate a political agenda decades after the President making the appointment has left office. Presidential appointment and Senate confirmation are also not necessary for judicial independence, and they seem to contribute to the politicization of the judiciary. Appointment by a non-partisan or bipartisan commission of some sort without Senate confirmation would increase independence, especially for lower court judges who might have a promotion in mind. The difficulty of overruling Supreme Court constitutional decisions also contributes to the problem. It might be better to include a mechanism, perhaps a congressional super-majority, to overrule Supreme Court constitutional decisions. As it is, the Supreme Court is not subject to any significant check in constitutional cases within its jurisdiction. The Court's behavior over time shows that selfrestraint is unlikely to be sufficient to rein in an activist Court.

Another problem with the Supreme Court is that the confirmation process has become a charade in which nominees with strong views on many subjects refuse to answer direct questions about their legal views and pretend that they will decide cases based on the law in a neutral fashion based only on the applicable law. This has disabled the Senate from explicitly evaluating nominees based on their politics, which is the main influence on their decisions in important cases. Chief Justice Roberts analogized the role of the judge to that of a baseball umpire calling balls and strikes. (As a certified baseball umpire, I found this analogy between baseball umpires

\footnotetext{
${ }^{20} 5$ U.S. 137 (1803).
} 
Beermann, The New Constitution, 11/18/2013

and Supreme Court Justices insulting. If our decisions as umpires were made the way Supreme Court Justices' votes are, we would not be allowed to continue umpiring.) No one is really fooled by this for two reasons. First, everyone knows that Supreme Court Justices disagree about politics and policy not about the law. Second, most of the important cases that reach the Supreme Court are not governed by any discernible legal doctrine, which is why Supreme Court review is necessary in the first place. For some reason, the highly political process of confirming Supreme Court nominations has become a shadow play with reality hidden behind layers of falsehood and obfuscation.

There is also no reason to maintain life tenure for federal judges. Non-renewable terms of 10,15 or 20 years would maintain independence while preventing outmoded views from becoming entrenched, and it would remove Presidents' incentive to appoint younger judges and Justices than might otherwise be the case. It would also make it much less likely that judges and Justices would continue to serve after their capabilities have become significantly diminished. If the appointment process were non-political, then renewal or life tenure might make sense, but under current circumstances, life tenure makes little if any sense.

\section{Dysfunction and the Congress}

Congress is the branch of government currently cited most for the problem of dysfunction. Gridlock in the Capitol building is worse than on the streets of mid-town Manhattan. The pathologies gripping each House of Congress are different. After first considering the problems caused by the separation of powers and the separation of the election of the President from congressional elections, this Part turns to considering the distinct causes of dysfunction and other problems in the House and the Senate.

A. Divided Government and Automatic Opposition 
Beermann, The New Constitution, 11/18/2013

The United States has a particularly strong form of separation of powers as compared with most western democracies because of the complete separation of Executive Branch personnel from Congress. The Constitution forbids simultaneous service in the legislative and executive branches. ${ }^{21}$ Further separating the Executive Branch from Congress is the independent election of the President and the Congress. These two constitutional features combine to produce divided government in which legislative leaders are cast in the role of opposition to the President. In recent times, this has been seen most starkly in the efforts of the leadership of the Republican-controlled House of Representatives to prevent the Affordable Care Act from going into effect which led to a partial government shutdown and the precipice of default on debt by the Government of the United States. The Democratic President's refused to negotiate with Congress during the shutdown and under the threat of default stymied efforts to achieve legislative compromise until global economic catastrophe due to a United States default became a real possibility, and even then the parties could agree on only a three month delay of the day of reckoning.

In most western democracies, after the election of 2012, the President's party would be able to govern without significant resistance from the minority party. In 2012, President Obama received 2 million more votes than his Republican rival Mitt Romney, and Democratic candidates for the House of Representatives received 1.4 million more votes than Republican candidates but partisan districting (more on this below) gave the Republican party a 33 seat plurality in the House of Representatives. According to an October 17, 2013 report on CNN, President Obama carried only 17 of the 242 House districts in which Republicans won election, meaning that the constituents of Republican House members' from 225 House districts may

\footnotetext{
${ }^{21}$ U.S. Const. Art 1, s. 6, cl 2 ("no Person holding any Office under the United States, shall be a Member of either House during his Continuance in Office").
} 
Beermann, The New Constitution, 11/18/2013

agree with the Republican party's efforts to stymie the Affordable Care Act. (Also according to the CNN Report, the 15 Republicans who voted in favor of the legislation ending the government shutdown were all from districts that President Obama carried in 2012, a stark representation of the consequences of partisan districts.) If Cabinet Secretaries were chosen from the ranks of Congress and if votes for President determined majority status in Congress, the brinksmanship of 2013 simply would not happen.

This is the system used in many parliamentary democracies. Voting among party activists chooses and ranks a list of candidates and each party is seated in the legislature in proportion to the votes received by their party. For example, if the legislature contains 100 seats, each party would put forward a list of 100 candidates, ranked in order of their entitlement to be seated. If Party A wins 55 percent of the vote and Party B wins 45 percent, the first 55 candidates on Party A's list would be seated, as would the first 45 candidates on Party B's list. Processes within each party would ensure diversity among the Members of Parliament in terms of geography and other salient characteristics such as policy, race and gender.

Are there good reasons to fear a switch to a system of proportional representation and majority control of the government? In the United States, the separation of powers is treated with mystical reverence as the primary method for preventing government tyranny. The fear is that if the same personnel occupy legislative and executive positions, power is concentrated and unchecked. In my view, there are reasons to be strongly skeptical of this widely accepted view both in terms of the negative consequences of adopting a parliamentary system and the positive effects of the current system in the United States.

On the negative consequences of the parliamentary system for freedom, the simple truth is that most of our European allies manage to preserve freedom under governments formed 
Beermann, The New Constitution, 11/18/2013

without separation of personnel and election between the legislative and executive branches. Germany, whose constitution was virtually imposed by the United States, ${ }^{22}$ is a shining example of a free society governed in the parliamentary method. There is no historical or social basis for the belief that allowing legislators to serve as Cabinet secretaries and linking the election of the President to votes cast for Congress would lead to a loss of liberty. As long as partisan gerrymandering played no role in congressional elections, this system is likely to produce a more democratically accountable government than the current system under the U.S. Constitution.

In fact, the positive consequences of the strict separation of powers, especially personnel, in the United States may be overstated. The strict separation of powers increases the potential for government secrecy and makes it more difficult for Congress to monitor Executive Branch activities. Consider recent revelations that the National Security Agency has been collecting information about every telephone call made in the United States and every email sent in the United States. Congressional involvement in the Executive Branch could decrease the ability of the government to invade people's privacy without detection. Members of Congress may not want to face their constituents' questions about such activity.

The separation of personnel between the Legislative and Executive Branches in the United States creates an automatic opposition even when both branches are controlled by the same party. Although oversight and obstruction are usually reduced in such circumstances, the two branches are still likely to disagree on major issues, for example involving international trade and public spending. A more unified structure of government might facilitate greater cooperation and less wasteful bickering and compensatory actions by the President to gain congressional agreement.

\footnotetext{
${ }^{22}$ In Germany, the Basic Law was often referred to as "unsere geschenkte Demokratie," which means literally "our gifted democracy," a gift of the United States.
} 
Beermann, The New Constitution, 11/18/2013

The parliamentary system presents its own risks of gridlock and dysfunction.

Proportional representation would eliminate two problems - partisan gerrymandering and the resulting possibility that the party receiving fewer votes gains a majority in the House of Representatives. If there are more than two viable parties and no party is able to command an electoral majority, coalition governments become necessary and extremist parties necessary to achieve majority status can have disproportionate influence on government policy, much as the Tea Party faction of the Republican Party seems to have today in the House of Representatives. With a closely divided electorate, third parties might be spawned and could move politics toward the extremes. In Israel, for example, the conservative Likud party often has to ally with extremist parties to gain a majority, just as the Republican Party must cater to its Tea-Party fringe elements. Although in some countries the parliamentary system produces relatively stable and productive governments, in others, such as Italy, the opposite has been the case. Closely divided elections can lead to protracted and even unsuccessful efforts to form a government and new elections every time the political winds shift direction. The point is thus not necessarily to suggest that the United States radically alter its system of government. Rather, this discussion is intended to point out that reverence for out particular brand of separation of powers may be unwarranted.

B. The Dysfunctional House.

In the House of Representatives, dysfunction appears to be partially a result of partisan gerrymandering of districts combined with a relatively close division among the electorate. The argument here is built upon the same factors as the criticism of the Supreme Court's campaign finance jurisprudence: partisan gerrymandering and the influx of corporate money into congressional campaigns have produced a Republican majority that is more conservative than 
Beermann, The New Constitution, 11/18/2013

would otherwise exist. Democrats received more votes in the most recent election yet they cannot even force the House leadership to bring a bill to a vote that would receive majority support in the House because the Speaker of the House, following a rule dating to the speakership of Newt Gingrich in the 1990s, has decided not to call a vote on any bill that lacks majority support among Republican House Members. The Speaker adheres to this rule to preserve his position as Speaker. Republicans are afraid to support moderate or liberal policies because of the potential for a well-financed primary election challenge from the right. The possibility of compromise has been destroyed.

There are reasons to be skeptical of this diagnosis. Even though Democrats received substantially more votes than Republicans, there may not be a broad national consensus behind Democratic Party policies. Further, party voting totals are not a reliable measure of voter support because voters in safe districts have little incentive to take the trouble to vote. Even the presidential election is an unreliable measure of policy support when the losing party puts forward a completely unqualified or an apparently extremist Vice-Presidential candidate, as the Republicans have done in the last two elections. ${ }^{23}$ Perhaps what is behind gridlock in the House of Representatives is the simple fact that the electorate is closely divided and has been for some time. With the "solid South" no longer Democratic and alternating two-term presidencies, it should not be surprising that there is serious disagreement within the House of Representatives. Unless and until a consensus coalesces around some set of political principles, such as Ronald Reagan's campaign against government regulation, it may unrealistic to expect any controversial legislation to sail through the House.

\footnotetext{
${ }^{23}$ The best evidence for how the extreme wing of the Republican Party has taken over is how far to the right Mitt Romney had to move to win the party's presidential nomination in 2012. His primary positions, which were so different from his behavior as governor of Massachusetts, made it virtually impossible for him to win a general election.
} 
Beermann, The New Constitution, 11/18/2013

The Constitution's provision granting each House of Congress the power to "determine" its "Rules of Proceedings" coupled with the Constitution's failure to specify a process for bringing bills to the floor of the House or Senate creates the conditions for this brand of gridlock. Rules granting the Speaker control over the House's agenda are unassailable as a constitutional matter and leave the minority powerless. (As discussed below, the power over rules also contributes to gridlock in the Senate by validating the filibuster and secret holds that allow a minority to control the Senate's agenda.) Rules and practices that may have worked in a less divided and contentious era have proven disastrous under current circumstances.

Another way to approach the issue of gridlock in the House would be to consider alternative selection methods. As discussed above, the most common alternative method of choosing representatives is through proportional representation of parties based on party vote totals without districts. As discussed, it is unclear that proportional representation would be a better solution to gridlock in the House than a concerted effort to eliminate partisan gerrymandering. This would require either political resolve to remove the partisan element in districting or perhaps a decision by the Supreme Court to show the same concern for the average voter's ability to influence elections as it does for corporations (and soon, to wealthy individuals). ${ }^{24}$ The Court could make it easier for voters to challenge partisan gerrymandering on equal protection grounds. While the Court has held that partisan gerrymandering can violate the Equal Protection Clause, ${ }^{25}$ the Court has made it very difficult to prove a claim, and the lower courts have followed the Supreme Court's lead and rejected most if not all such claims. ${ }^{26}$

\footnotetext{
${ }^{24}$ McCutcheon v. Federal Elections Commission, 893 F. Supp.2d 133 (D.D.C. 2012) (three judge court), probable jurisdiction noted by $133 \mathrm{~S}$. Ct. 1242 (2013).

${ }^{25}$ Davis v. Bandemer, 478 U.S. 109 (1986); Vieth v. Jubelirer, 541 U.S. 267 (2004).

${ }^{26}$ See Larios v. Cox, 300 F. Supp.2d 1320 (N.D. Ga.) (finding violation of one-person one-vote principle due to population disparities in state legislative districts but rejecting partisan gerrymandering claim) affirmed, 542 U.S. 947 (2004). Justice Scalia's dissenting opinion from the Court's summary affirmance in Larios is worth reading because it reflects the Court's deferential view toward partisan gerrymandering claims. Id. at 948.
} 
Beermann, The New Constitution, 11/18/2013

The particular pathologies that have emerged in the House in recent years seem to be connected more than anything to partisan gerrymandering. In former times, once a major statute like the Affordable Care Act was enacted into law, the minority would allow it to go into effect without shutting down the government as part of a campaign to defund it. The minority might continue to press for amendment or repeal through ordinary legislative channels, and if the law turns out to be as problematic as Republicans claims is the case regarding the Affordable Care Act, it might actually be repealed ${ }^{27}$ or substantially altered. But the minority would not hold the entire government hostage to its efforts. Today, with gerrymandered districts and the influx of corporate money into House elections, Members from strongly Republican districts are encouraged to take whatever steps are possible to attack the President's program, and even after the shutdown many Americans applauded their Representatives for fighting a good fight.

\section{The Dysfunctional Senate}

The United States Senate led the way out of the recent government shutdown/debt limit increase crisis, so it might be thought that today the Senate functions better than the House of Representatives. The Senate is clearly not in the grips of a Tea Party inspired insurgency. Although Republican Senators may not like the Affordable Care Act, as a body the Senate has not engaged in the same destructive tactics as their House counterparts, much to the chagrin of Senator Ted Cruz of Texas, who has blamed the Senate Republican leadership for caving in to the President's "no negotiations while the government is closed or over default" strategy. Yet in the long term, the Senate is a much more deeply flawed institution than the House and, in my view, should either be abolished or relegated to a purely advisory role without the power to

\footnotetext{
${ }^{27}$ For example, the Medicare Catastrophic Coverage Act of 1988 (P.L. 100-360), was repealed in 1989 after seniors realized that they would be paying the entire cost without necessarily receiving much in the way of benefits from the program. See T Rice, K Desmond \& J Gabel, The Medicare Catastrophic Coverage Act: A Post-mortem, 9 Health Affairs 75 (1990).
} 
Beermann, The New Constitution, 11/18/2013

prevent the House from passing legislation and presenting it to the President. Barring that, dramatic structural and rules reforms should be adopted to ameliorate the Senate's negative influence.

Beginning with the most obvious, the makeup of the Senate is terribly anti-democratic. With each State large and small entitled to two Senators, the Senate can repeatedly frustrate the will of a vast majority of the people of the United States simply by voting with no fancy rules footwork necessary. In 2010, the 26 least populous States contained about 18.5 percent of the population of the United States, giving Senators representing less than one-fifth of the population a veto power over federal legislation. Regardless of the role this structure played in the compromises necessary to ensure adoption of the Constitution in 1789 , its incompatibility with democratic governance is clear. That is why the Supreme Court long ago prohibited States from apportioning their legislatures through geography rather than population. ${ }^{28}$

The Senate's longstanding rules and practices exacerbate this problem. Most prominently, the Senate's rules require 60 votes to cut off debate, ${ }^{29}$ giving Senators representing an even smaller minority (approximately 10 percent) of the American people an effective veto over legislation, appointments and treaties through the use of the filibuster. Slowly but surely the use of the filibuster has increased in recent decades so that today the Senate has become virtually governed by a super-majority rule. Even more pernicious is the Senate's rule allowing individual Senators to place holds on appointments and legislation, allowing in effect a single Senator to prevent a vote on an appointment or policy that might enjoy overwhelming support

\footnotetext{
${ }^{28}$ Reynolds v. Sims, 377 U.S. 533 (1964).

${ }^{29}$ Standing Rules of the United States Senate, Rule XXII
} 
Beermann, The New Constitution, 11/18/2013

among the people. ${ }^{30}$ This is even done secretly: Senators can place holds by privately informing the leadership of their objection to a matter.

Once again, the constitutional culprit here is the provision allowing each House of Congress to establish its own rules. ${ }^{31}$ Rather than set forth a reasonable set of rules governing the legislative process, the Constitution leaves it to each House to structure its proceedings. In the Senate, the practice has been to require a two-thirds vote to cut off debate on a question of amending the rules, which allows a small minority to prevent reform. The Senate's role as obstructer-in-chief of majority rule is entrenched in both the Constitution and the Senate's own rules.

Of course, the blame for the Senate's recent devolution into an obstructionist, antimajoritarian institution rests more on the people involved than the Constitution or the Senate's rules. For many decades, the Senate functioned relatively smoothly in a system in which it was understood that the filibuster was appropriate only in extremis so that under most circumstances, the minority did not obstruct everything. Just as a car can be driven within or over the speed limit, so many Senators have found it useful to exploit the rules to obstruct their political opponents that institutional limits are necessary to limit the damage.

Another problem caused by the Senate is increased pork barrel legislation. Just as House Members bring projects to their districts, Senators bring large projects to their States. With more constituents, Senators need larger and more prominent projects. It is not surprising that funding for a \$2 billion dam project in Kentucky (home State of Senate minority leader Mitch McConnell) was included in the recent legislation reopening the government and raising the debt limit for three months. Without support from Massachusetts Senators, the \$24 billion Big Dig

\footnotetext{
${ }^{30}$ Standing Rules of the United States Senate, Rule VII.

${ }^{31}$ U.S. Const. Art I, $§ 5$.
} 
Beermann, The New Constitution, 11/18/2013

never would have been built, even at its original price tag of $\$ 2$ billion. Senators also employ a small army of caseworkers, providing duplication of the House's network of constituent services. $^{32}$

The simplest solution to the problem would be to eliminate the Senate. Any utility derived from having a second legislative chamber may be outweighed by actual and potential damage caused by the Senate's anti-democratic structure and its pork barrel propensities. The loss of the Senate's deliberative contribution to the lawmaking process could be ameliorated by increasing the size of the House by 50 or 100 members, although this could actually make matters worse because of the difficulty of managing deliberation in a 500 person assembly. Another major loss if the Senate were abolished might be the loss of a good training ground for Cabinet Secretaries but with a single chamber, the status of House committee chairs and other leaders would increase and the House could become a more important source of presidential appointees.

Barring abolition, another possible reform would be to limit the Senate's power over legislation to sending bills passed by the House back to that chamber for reconsideration. The requirement of bicameral passage of legislation, with an undemocratic chamber, is inconsistent with democracy and serves no useful purpose that would not also be served by limiting the Senate's power as suggested. As a debating society with the ability to delay the presentment of legislation to the President by majority vote within a stated period of time, the Senate would slow down the legislative process and facilitate deliberation without allowing the minority obstructionism inherent in the current design and practices of the Senate. The Senate could also take responsibility for reviewing administrative rules with the power to recommend rejection by the House under the Congressional Review Act, and it could continue to participate in oversight

\footnotetext{
${ }^{32}$ See Morriss P. Fiorina, Congress: The Keystone of the Washington Establishment (Revised Edition 1989).
} 
Beermann, The New Constitution, 11/18/2013

more generally. Again, this would serve the purpose of increased deliberation and oversight while eliminating a substantial source of gridlock and pork barrel activity.

Even if the Senate is maintained as an equal partner with the House of Representative in the legislative process, I would suggest some different reforms. The most important reform would be to strip the Senate of its power to reject presidential appointments. The Senate uses its advice and consent power on appointments to extort concessions from the President, including the appointment of overly political former congressional staff members to positions on independent agencies. Independent agencies are intended by Congress to be independent of the President but not of Congress, and Congress uses the Senate's advice and consent power to perpetuate its influence on agencies. While there is nothing wrong in principle with legislative influence over agencies, it should be above board and not through the informal back channel methods of communication used under current practice.

Another reason to eliminate the Senate's advice and consent authority over appointments is that the Senate uses that power as leverage over legislative and oversight matters having nothing to do with the qualifications of nominees. On October 28, 2013, Senator Lindsay Graham apparently announced the following: "I'm gonna block every appointment in the United States Senate until the survivors [of the attack on the U.S. consulate in Benghazi, Libya] are being made available to Congress. I'm tired of hearing from people on TV and reading about stuff in books. We need to get to the bottom of this." ${ }^{33}$ Recent events involving the Consumer Finance Protection Bureau and the National Labor Relations Board further illustrate this problem. With regard to the CFPB, the most qualified candidate to head that agency, Elizabeth Warren, was so controversial among Republican Senators that the President couldn't even

\footnotetext{
33 Ted Barrett, Blog, Obama nominees could be slowed over Benghazi concerns, http://politicalticker.blogs.cnn.com/2013/10/28/obama-nominees-could-be-slowed-over-benghaziconcerns $/$ ?hpt $=h p \_t 2$.
} 
Beermann, The New Constitution, 11/18/2013

nominate her. Republican Senators held up Richard Cordray's nomination to head the CFPB for two years not because of doubts about him but because they wanted substantive changes to the agency's statutory powers. With regard to the NLRB, the Senate didn't confirm anyone for years, which stymied the agency's ability to function. ${ }^{34}$ These controversies have led to the current dispute over President Obama's recess appointments. If, as many expect, the Supreme Court agrees with the Courts of Appeals ${ }^{35}$ and places severe limits on recess appointments, the Senate will have the power to close down important federal agencies indefinitely simply by not confirming appointments without having to make any substantive legal changes. This could elevate gridlock in Washington to new heights. While some view the Recess Appointments Clause as an anachronism under current conditions of communication and transportation, in my view the advice and consent requirement is the anachronism because it is overused by an undemocratic Senate. ${ }^{36}$

The Senate's power over judicial appointments is also of dubious utility and creates spectacular political shows while prejudicing the federal courts' ability to function. Some judgeships stay open for years as each party refuses to allow confirmation of nominees by Presidents of the other party, especially to important courts like the Court of Appeals for the District of Columbia Circuit. The majority party in the Senate sometimes turns away nominees without even holding hearings or taking a vote-it simply sits on them until Congress's session

\footnotetext{
${ }^{34}$ See New Process Steel v. NLRB, 130 S. Ct. 2635 (2010) (holding that NLRB cannot issue binding orders without at least three members).

${ }^{35}$ See NLRB v. Enterprise Leasing Co. Southeast, 722 F.3d 609 (4th Cir.2013); NLRB v. New Vista Nursing and Rehab., LLC, 719 F.3d 203 (3rd Cir.2013); Noel Canning v. NLRB, 705 F.3d 490 (D.C. Cir.2013), cert. granted, 133 S. Ct. 2861 (June 24, 2013).

${ }^{36}$ Interestingly, after lamenting the undemocratic nature of the Senate, Sanford Levinson decries recess appointments as "a device by which presidents can simply avoid the necessity of confronting senatorial disapproval of potential nominees" and "an anachronism and a potential vehicle for presidential abuse." Levinson supra note $\mathrm{x}$ at 111-12. Why should we care if the President makes an end run around the undemocratic Senate? I do not mean to criticize Levinson for inconsistency: The Constitution is so full of defective provisions that inconsistency in pointing out the defects is inevitable.
} 
Beermann, The New Constitution, 11/18/2013

ends or the nominee tires of waiting in limbo. In the meanwhile, there are a number of unfilled judicial positions in some courts with heavy workloads. President Obama has not even nominated anyone to fill many of the judgeships. This may be due in part to the relatively slow pace on such matters in his administration, but it may also be due to the rigors of Senate confirmation, which cause the President to be extremely careful before putting anyone forward.

The positive utility of the Senate's confirmation process is far outweighed by its costs including its contribution to gridlock and its use to extract concessions and appointments of congressionally suggested candidates. Of course, the Senate has sometimes prevented the President from making extremely bad appointments. However, assuming that the Senate continues to function as it does today, with secret holds and the super-majority requirement, the Senate's power to reject presidential nominations of federal judges and other Officers of the United States should be eliminated. In order to provide some check on judicial appointments, an independent commission could be substituted for the Senate, perhaps with the power to reject nominations by vote held within a specified period of time. If the Senate's role is preserved, a time limit should be placed on Senate action, and failure to vote negatively on a nominee within the specified period of time, perhaps 90 days, should result in confirmation. ${ }^{37}$ This would at least eliminate the Senate's ability to hold up appointments without even voting or taking any other public action.

Assuming its continued existence, the composition of the Senate should be reformed to make it more representative of the people. States should be allocated Senators based on population, perhaps with the bottom third of States receiving one Senator, the middle third two

\footnotetext{
${ }^{37}$ This reform, like many discussed in this essay, may require a constitutional amendment. However, given the lack of clarity in the term "advice and consent" in the Constitution, perhaps this reform could be accomplished legislatively or through Senate rules. A statute or a rule could specify that any nomination not rejected within 90 days of submission is deemed to have been consented to by the Senate.
} 
Beermann, The New Constitution, 11/18/2013

and the most populous third three Senators. While this allocation is far from perfect, it is much closer to a fair allocation of legislative power to the people of the United States. As discussed below, as part of this reform, strength in the Senate should have nothing to do with the presidential election since the composition of the Senate, currently or under this proposed reform, strays too far from the democratic ideal.

\section{Dysfunction and the Presidency}

Many of the examples of constitutional dysfunction discussed above obviously touch on the power of the presidency, simply through the obstructionist power of a minority within Congress or of Members of Congress representing a minority of the American people. Recent decades have seen strong and weak Presidents, and the most important variable seems to be the character of the President. However, constant hounding from Congress certainly weakened Bill Clinton's presidency and vehement congressional opposition has weakened Barack Obama's presidency. In this Part, I briefly discuss how the current political and constitutional situations have brought dysfunction to the Presidency, and how the system of presidential election damages the country.

\section{A. Presidential Dysfunction}

Although Levinson and Ackerman focus on different constitutional problems, they seem to agree that the principal problem with the presidency is that the President is too powerful. Ackerman's entire book is devoted to presidential excess in military, foreign affairs and domestic matters. While Levinson's primary focus is on the democracy deficit in the current federal government, he decries presidential power, agreeing with the characterization of current practice as "presidential autocracy.",38

\footnotetext{
${ }^{38}$ Levinson, supra note $\mathrm{x}$ at 109.
} 
Beermann, The New Constitution, 11/18/2013

Ackerman's concern about the presidency is understandable because his analysis is deeply reactive to the excesses of the presidency of George W. Bush. Given Levinson's concern about democracy, I find his view of the presidency surprising. In my view, the greatest effect of abusive practices and gridlock in Congress has been to sap the President's ability to govern effectively. Congress stymies the President by creating independent agencies and placing congressional loyalists at the head of those agencies, by delaying or rejecting presidential appointments and by near constant intervention into the functioning of the entire Executive Branch. ${ }^{39}$ Congress has numerous formal and informal tools at its disposal to prevent the President from acting, and over time it has become less and less shy about deploying them.

It is impossible to know whether vehement opposition in Congress has contributed to Barack Obama's lackluster performance as President. The disastrous roll out of the Affordable Care Act website, and the President's apparent lack of genuine concern is emblematic of his presidency. By contrast, a President like Lyndon Johnson might have been at a computer terminal trying the website himself before the rollout and he would have either made sure it worked or he would have been announcing personnel changes as soon as the problems became apparent. The undemocratic Congress has ample means to prevent the President from achieving most if not all of his policy goals. In my view, the concerns that Ackerman and Levinson express about the power of the presidency are misplaced and if they represent any trace of reality, the problems are not traceable to constitutional or institutional structures but derive more directly from the personality and character of particular presidents.

Levinson laments the rigid terms in office established by the Constitution. Other than impeachment for serious criminal conduct or demonstrated disability, there is no way to remove

\footnotetext{
${ }^{39}$ See Jack M. Beermann, Congressional Administration, 43 San Diego L. Rev. 61 (2006).
} 
Beermann, The New Constitution, 11/18/2013

or suspend ${ }^{40}$ the President until the end of the constitutionally prescribed term. Paradoxically, the inability to remove a weak President may weaken the presidency, because there may be extended periods during which the President is politically crippled and the balance of power shifts toward Congress. This raises the question whether a reform that included a process for removing the President such as a no confidence vote in Congress would help or hurt in this regard. It would be impractical to institute such a reform without connecting the election of the President to the election of Congress because otherwise the President would be in constant danger, and thus seriously weakened, whenever Congress was in control of the other party.

Jeremy Paul has argued that term limits weaken the presidency, because every two-term President is a lame duck from the first day of the second term and because popular, experienced Presidents are forced from office prematurely. ${ }^{41}$ In my view, the twenty-second amendment's limitation of Presidents to two terms provides an important check on presidential overreaching. Without such a limitation, Presidents might act on the incentive to stay in power forever in destructive ways including attacks on democracy and freedom. The loss of influence in the second term and expertise when an experienced President leaves office after eight years is worth it. $^{42}$

The most interesting questions concerning the American version of separation of powers involve the political status of Department Heads and other high level Executive Branch officials. In this system, most such officials have little or no political base independent of the President. The only significant political pressure on the President involving appointments is the potentially negative voice of the Senate. The questions, which are impossible to answer, are whether the

\footnotetext{
${ }^{40}$ U.S. Const. Amend. XXV, § 4.

41 See Jeremy Paul, If It Quacks Like a Lame Duck, Can It Lead the Free World?: The Case for Relaxing Presidential Term Limits, 43 Conn. L. Rev. 1097 (2011).

${ }^{42}$ See Jack M. Beermann, A Skeptical View of a Skeptical View of Presidential Term Limits, 43 Conn. L. Rev. 1105 (2011).
} 
Beermann, The New Constitution, 11/18/2013

President is strengthened because all Cabinet members and many other high level officials owe their appointments to the President or whether the overall political power of the Executive Branch would be enhanced if Cabinet members had independent political bases. A more vigorous Executive Branch might increase the power of the presidency.

In this regard, it is not surprising that President Obama has appointed party leaders (and previously powerful legislators) as the arguably most important Department Head, Secretary of State. Perhaps the overall strength of the Executive Branch would be increased if Cabinet Members could continue to serve in Congress. This might also limit the President's power to act unilaterally.

\section{B. The Dysfunctional Presidential Election System.}

I don't believe I have to go into great detail concerning the anachronistic and potentially dangerous method of electing the President of the United States. The Electoral College was designed at a time when the Framers of the Constitution limited the vote to significantly less than half of the adult population of the country, and even then they were so concerned that the people would make an unwise choice that they placed the Electoral College as a buffer between the people and the selection of the President. While State-by-State voting for electors entails the possibility that the President can be elected without winning the popular vote, the most pernicious feature of the system is that each State is granted two votes based on their representation in the Senate. ${ }^{43}$ Because representation in the Senate is unrelated to population, this dramatically increases the possibility that the less popular candidate becomes President. It is why George W. Bush defeated Al Gore in 2000-Gore won 20 States while Bush won 30, so even though Gore received more votes and won States representing more population than the

\footnotetext{
${ }^{43}$ At the time of the adoption of the Constitution, the provision counting slaves, who had no rights and certainly could not vote, as $3 / 5$ of a person in the census was more pernicious because this dramatically increased both representation in Congress and influence over presidential elections for the slave states. See U.S. Const. Art. I § 2.
} 
Beermann, The New Constitution, 11/18/2013

States won by Bush, he lost the election when the Supreme Court ordered the recount in Florida to stop.

The only saving grace of the Electoral College is that it can make a close election look less close. Even a close popular vote can result in a decisive margin the Electoral College. In my view, this is an insufficient virtue to save the Electoral College from the charge that it serves virtually no useful purpose and poses a grave threat to democracy. It should be abolished, and barring that States should not receive two extra votes each based simply on the number of Senators.

The Electoral College is under attack by the current popular National Popular Vote movement, in which States promise to award electors to the winner of the popular vote if enough States have passed legislation so that the popular vote winner would be guaranteed to win the vote in the Electoral College. ${ }^{44}$ According to the movement's website, legislation has been passed by nine States and the District of Columbia, representing 136 electoral votes, or a bit more than half the number needed to elect the President. If enough States were to pass this legislation, the inevitable constitutional challenges to it could touch off the most interesting Supreme Court decision in the history of the United States. The movement claims that there is no constitutional impediment to this change, ${ }^{45}$ relying in part on the fact that some States currently award electoral votes by congressional district rather than by the winner take all system operative in most States. Although it may be apt, that is an unfortunate precedent, because it potentially increases the negative consequences of gerrymandering of congressional districts. While it does demonstrate that winner take all is not the required system of awarding a State's electors, it is less than clear that a State could provide by law that all of its electors can be

\footnotetext{
${ }^{44}$ See http://www.nationalpopularvote.com/.

$45 \mathrm{http}: / /$ www.nationalpopularvote.com/pages/answers/section.php?s=1\#m1_1.
} 
Beermann, The New Constitution, 11/18/2013

awarded to a candidate that did not win the vote in that State. In my view, that presents a serious constitutional question. $^{46}$

The crazy and indefensible system of selecting the President of the United States cannot be good for the country. Selection of an illegitimate or minority President can lead to polarization both among government officials and the people generally and can deflate overall support for the government. A simple system in which the candidate receiving the most votes was elected, or perhaps a more complicated system of runoffs or an instant runoff on the initial ballot to ensure majority support for the President would be significantly better than the current Electoral College method. This is a constitutional reform that is long overdue.

\section{Dysfunction and Constitutional Amendment}

One of Sanford Levinson's strongest criticisms of the United States Constitution is that it is too difficult to amend. Levinson claims that Article V, which requires proposal by two-thirds of Congress (or a convention called by two-thirds of the States), and ratification of three-quarters of State legislatures or State conventions for any amendment to the Constitution, creates the most difficult amendment process in the world.

As both Levinson and Ackerman recognize, the Constitution has in effect been amended informally, mainly by Supreme Court acceptance of changes initiated by other government actors to deal with new social problems, most notably the Court's eventual acquiescence in economic regulation and structural change during the New Deal. However, many of the structural reforms suggested in this paper and by others could not be accomplished legislatively would never be agreed to by a sufficient number of States to be enacted under Article V. Less

\footnotetext{
${ }^{46}$ The Supreme Court has stated that States have plenary power to determine the method for selecting presidential electors. See McPherson v. Blacker, 146 U.S. 1, 35 (1892). That does not mean that State power is unlimited. Imagine, for example, a State law that simply promised its electors to the candidate coming in second in the State's popular vote. Would that be constitutional? Bush v. Gore, 531 U.S. 98 (2000), implies that State law concerning the awarding of electors is subject to a significant measure of federal control.
} 
Beermann, The New Constitution, 11/18/2013

populous states stand to lose too much power if, for example, the Senate or the method of selecting the President were made more democratic.

I agree with Levinson that Article V's process is too restrictive, but based on history, mainly the precedent of the replacement of the Articles of Confederation with the Constitution of 1789, I don't think that Article $\mathrm{V}$ is binding. In my view, the precedent set by the Framers of the Constitution establishes that a number of States could band together and write a new Constitution without following Article V. Recall that the full name of the first Constitution of the United States was the "Articles of Confederation and Perpetual Union." Article XIII of the Articles provided that "the Articles of this Confederation shall be inviolably observed by every State, and the Union shall be perpetual; nor shall any alteration at any time hereafter be made in any of them; unless such alteration be agreed to in a Congress of the United States, and be afterwards confirmed by the legislatures of every State." Although the Framers of the Constitution originally set out in the late 1780 s to amend the Articles, they quickly turned to a complete rewrite and provided in Article VII that the new Constitution would go into effect upon the ratification of nine States, ignoring the Articles' unanimity requirement.

Following this precedent, a group of populous States could convene a constitutional convention, invite representatives of all 50 States, and adopt a new Constitution without abiding by Article V's process. For example, the twenty most populous States contain about two-thirds of the population of the United States. If they drafted a new Constitution, for example identical to the current Constitution but with some of the modifications suggested above, they could provide that the new Constitution goes into effect if ratified by fifteen of those twenty States, or by States representing a specified percentage, say 60 percent, of the population. This new Constitution could include transition rules such as maintaining the current federal courts, 
Beermann, The New Constitution, 11/18/2013

adopting all federal statutes and assuming all assets and liabilities of the current government. Just as Americans applauded the democratization of Eastern European nations in the 1990s, so too would the world applaud the democratization of the United States. As outsiders, we were not concerned with whether revolutionary change in those countries was accomplished within the limits of preexisting law. Although Sanford Levinson points out that WWALD (What Would Abraham Lincoln Do) is not the proper standard for determining whether the government is violating the Constitution, ${ }^{47}$ for Americans to condemn this process for not following Article $\mathrm{V}$ would be to condemn George Washington, James Madison and others for their creativity in abandoning the strictures of the defective Articles of Confederation. I don't mean to propose a rigid WWGWD standard for evaluating the constitutionality or even desirability of my proposal, but I do find it instructive and inspiring that when the Articles of Confederation proved to be a failure, the Framers ignored Article XIII of that document and put into effect a new Constitution without following the Articles' procedure for amendment.

\section{Conclusion}

The Constitution has failed the people of the United States in so many ways that it is time to think seriously about making significant changes to it or perhaps replacing it altogether. The Constitution should ensure that the House of Representatives be truly representative of the people who elect the Members. The undemocratic-by-design Senate should either be abolished or restructured and it should not have the power to reject legislation that has passed the House of Representatives. The Supreme Court, and perhaps the lower federal courts, should be reformed to prevent the judicial power from becoming the power to prevent democratic governance. The President, and Members of Congress, should be selected in a democratic method free from the

\footnotetext{
${ }^{47}$ See Levinson, supra note $\mathrm{x}$ at 105-06 (discussing Michael Stokes Paulsen's use of the argument that if he is mistaken, so was Abraham Lincoln).
} 
Beermann, The New Constitution, 11/18/2013

overwhelming influence of big money donors who pervert both the electoral system and the process of government. Something has to be done to end the cycle of lurching from crisis to crisis without any real planning or rational debate. The time for change has arrived.

Exactly what form that change should take is another matter. Should the United States follow the European model and adopt a system that unifies the election of the legislative and executive branches of government, ensuring majority support for the party of the President? Should Members of Congress also be allowed to serve as Cabinet Members? Should the Supreme Court's power be limited, for example by allowing a 2/3 vote in Congress to override constitutional decisions or by limited Justices' terms to 10,15 or 20 years? Should the popular vote determine who is elected President? Should there be a runoff or an instant runoff on the initial ballot to guarantee a majority vote for whomever is elected? These and more questions must be answered to determine the best design of the government of the United States going forward. 